\title{
Delivering Multilingual Schools - Emergence and Development of Language Beliefs in Immigrant Teachers
}

\author{
Galina PUTJATA \\ University of Münster \\ E-mail: putjata@wwu.de
}

\begin{abstract}
How Come We Don't Deliver?" asks Elana Shohamy in the title of her paper on imagined multilingual schools and tackles the striking issue in education: the need for a paradigm shift towards a multilingual approach. This paper focuses on the role of immigrant teachers in this process. Based on the sociolinguistic framework of linguistic markets and the pedagogical framework of professionalization, it presents a qualitative study on teachers' language beliefs. Using linguistic biographies, this study reconstructs how beliefs towards multilingualism emerge and develop under different educational settings. The findings indicate significant deviations in the perception of multilingualism and showcase deep insights into the development of these perceptions over time. The results reveal the importance of socio-political setting and contribute to a reflected understanding of linguistic diversity management in multilingual education and the need for teacher professionalization.
\end{abstract}

Keywords: multilingual education, immigrant teachers, language biography

\section{Multilingual Turn in Education}

Multilingualism, how it emerges and develops, depends on various individual and social factors, among others, the ways linguistic diversity is managed within the society (J. Blommaert 1999, J.T. Irvine/ S. Gal 2000, M. Schmid 2010). Strikingly, most European countries are characterized by monolingual norms (S. Gal 2006, C. Hélot/ A. Young 2006, G. Putjata et al. 2016). These monolingual norms affect the linguistic development of individuals and can lead to language rejection or loss (M. Schmid 2010). In addition, empirical data and normative discourse in pedagogy suggest that this approach also leads to underperformance of migrant-induced multilingual students at school. Multilingualism as social reality, impacted by the long history of transnational mobilities, globalization, and recent immigrant influx, have led researchers across the world and across different disciplines (e. g. sociology, linguistics, education) to call for a paradigm shift towards multilingualism (A. Pavlenko/ A. Blackledge 2004, S. Gal 2006, J. Blommaert 2010, P. Stevenson 2011, S. Fürstenau 2016).

Strong arguments from psycholinguistic (J. Cummins 2010, G. Poarch/ E. Bialystok 2017) and socio-political (J. Cummins 2010, C. Baker 2011, O. García 2013) perspectives emphasize the importance of multilingualism. In multilingual education, these arguments have been supported by empirical evidence on the microlevel of classroom and on the meso-level of school development: studies on the use 
of multilingual teaching practices (A. Creese/ A. Blackledge 2010, I. Oomen-Welke 2013, O. García/ Li Wei 2014) and the implementation of immigrant languages as part of school's curriculum confirm positive outcomes for multilingual learners themselves as well as their peers.

In spite of these psycholinguistic and socio-political arguments and the existing multilingual methods and strategies of school development, these multilingual educational strategies still lack regular implementation in practice. Research in countries like Germany, Belgium, France, Australia and Greece reveals prevailing monolingual beliefs (A. Gkaintartzi et al. 2013, R. Pulinx/ V. van Avermaet 2015, A. Young 2014, A. Schalley/ S. Eisenchlas/ D. Guillemin 2015, S. Fürstenau 2016, G. Putjata in press a). "How Come We Don't Deliver?" asks Elana Shohamy (E. Shohamy 2006) in the title of her paper on imagined multilingual schools and tackles the critical of issue of: How can language beliefs at school be transformed?

\subsection{Immigrant Teachers as Change Agents}

A key role in this transformation process has been politically assigned to immigrant teachers as experts in dealing with linguistic and cultural diversity. This perspective has led political actors across the world to call for a more diversified teacher population (CNN Wire Staff 2010, BReg. 2015, R. Ingersoll/ H. May 2016). Until now, little or no evidence has been established that supports this presumption. The present paper investigates language beliefs and their development in immigrant teachers. This paper will begin by presenting the theoretical framework on language beliefs from sociolinguistic and pedagogical perspectives and also provide a brief research overview of the issue. The second part of this paper will focus on a study that reconstructed the development of language beliefs in immigrant teachers based on the methodology of linguistic biographies. The final part of this paper will detail the opportunities and limitations of immigrant teachers as change agents and discuss implications for a multilingual paradigm shift in education.

\subsection{Theoretical Framework}

This study focuses on language beliefs from a sociolinguistic and pedagogical perspective. From the sociolinguistic perspective, teachers' language beliefs are subject to societal beliefs and reflect the values and practices of the community. J.T. Irvine and S. Gal (2000) argue that prevailing language ideology, based on social and political factors, impacts social institutions such as families, workplaces and care institutions. According to P. Bourdieu (1990), language constitutes a particular form of capital since languages and language varieties have different values within society which correspond to the prevailing hierarchy of societal power relations. A certain way of speaking, i.e. state language or minority language, reflects the origin of a person and their social background. In everyday conversation speakers of a minority variety can subconsciously be perceived as less skilled, while the majority language functions as cultural capital. On the level of the individual speaker, these considerations of usefulness are represented and reflected in beliefs which each speaker holds about the world. Language beliefs can comprise ideas about the role 
which particular language competences play in society, how languages are learned and how useful and valuable they are (P. Garrett 2010). These hierarchical differences in language status are socio-politically constructed. The educational system plays a predominant role in this process. Policy makers and teachers share ideas about language use, acting as "ideology brokers" (J. Blommaert 1999) and circulating beliefs about the value of particular linguistics resources, e.g. the competence to use two or more languages in everyday interactions. On the individual level, this is where the minority speakers learn the value of their language. Through teachers' feedback, the individual realizes which language is considered legitimate in interaction, while deviations such as the use of minority languages can be sanctioned. Thus, teachers produce and reproduce the societal power relations within the hierarchy of languages (P. Bourdieu/ J.-C. Passeron 1998).

From the pedagogical perspective, beliefs constitute one of the three core components of teachers' professional competence: knowledge, strategies of action and beliefs (J. Baumert/ M. Kunter 2006). Knowledge is described as a cognitive component and is comprised of the information teachers have about a subject. Strategies of action describe the pedagogical dimension of how teachers behaviour towards their students. In contrast to these two components, language beliefs are subjective and thus their nature differs significantly from the content or methodological knowledge. They are affectively loaded and embrace normative and judgmental ideas about learning processes. These ideas are not argument-based and also in research, the term 'belief' is still considered a 'messy construct' (M. F. Pajares 1992, B. Leutwyler et al. 2014). Studies in educational research conclude that teachers' knowledge and beliefs shape pedagogical practices and student outcomes (D. Woods 1996, D. Freeman 2001, K. Reusser et al. 2011). However, beliefs are discussed in particular as being resistant to change (F.C. Staub/ E. Stern 2002, L. Hall 2005). For teachers with limited knowledge about multilingual development, the resulting lacunas are filled by bilingual myths, revealing a series of language beliefs (R. Tracy 2008, F. Grosjean 2010). For example, teachers may believe that multilingual students mix languages due to confusion or lacking competence and that multilingualism is harmful for linguistic and cognitive development. These beliefs result in a series of monolingual practices: teachers try to prevent children from speaking family languages among each other on the playground or recommend parents to speak the language of schooling at home (O. Ağırdağ et al. 2014, G. Putjata in press a).

In this conceptual framework, teachers with an immigrant background may constitute a considerable resource. Being persons of authority and members of a respected societal group, immigrant teachers would be able to question the existing language hierarchy in their feedback on migrant languages and represent the legitimacy of migrant languages in everyday interaction. This, however, would require the perception of multilingualism as capital on behalf of the teachers. Until now, the question of immigrant teachers' perception of multilingualism remained underresearched (but see K. Bräu et al. 2013, D. Lengyel/ L. Rosen 2015, G. Putjata in press b). In order to investigate the actual potential of immigrant teachers 
advocating for an educational shift towards multilingualism, a deeper insight into their own multilingual upbringing and their everyday multilingual practices and beliefs is necessary. To capture this multilingual perception and its development, a qualitative study was conducted using the method of linguistic biographies in Israeli teachers with an immigrant background.

\section{Research Design and Methodology}

The data was gathered during field research in Israel in 2015. This geographic context was selected as the research site as it constitutes a particular interest in light of language and education. Since Israel's foundation, special priority was given to linguistic assimilation, with Hebrew as the only legitimate language: "Ivri, daber Ivrit!" (Hebrew person, speak Hebrew!). This slogan was usual on the dishes given to the new arrivals in the kibbutzim of the communities receiving the immigrants (J. Burteisen 2003). This language policy officially changed in the 1990s, after almost one million people from the Soviet Union and North Africa arrived in Israel (B. Spolsky/ E. Shohamy 1999). For the first time, the Ministry of Education officially declared Israel an immigrant country in need to transform its educational system. This call is revolutionary, as in most countries the educational system tends to preserve its monolingual approach, assimilating immigrant populations into the existing educational system (M. Krüger-Potratz 2009).

In order to cope with the rapid increase in numbers of students and the linguistic diversity present in the classrooms, immigrant teachers were to be integrated into the regular school system. Following the top-down policy on "New immigrant teacher absorption" a program was developed by the Ministries of Education and Absorption that allowed to adjust the teaching diploma to the Israeli system (E. Berger 2001). A few years later, the Ministry underlined the importance to maintain the linguistic heritage of the arrived population. In 1995, an official "New Language Education Policy" was implemented which encouraged newly arriving students to learn Hebrew and maintain family languages at the same time. For example, Hebrew classes were complemented by five weekly hours of Russian language and history, and Russian as a subject could be selected instead of or in addition to other foreign languages (B. Spolsky/ E. Shohamy 1999). This increased the need for teachers who would be able to provide these courses and established further opportunities for teachers' professional integration.

\section{(1) Data Collection: Language Biographies}

Data were gathered through narrative in-person interviews focusing on linguistic biographies (R. Franceschini 2002). Interviewees were asked to reflect freely on which languages they speak to whom and how it has changed over time. The selected data collection instrument is language biographies, to enable the researcher's access into the individual speaker's perspective on their linguistic lives. By reconstructing their own linguistic biography, interviewees not only reveal their subjective theories on language acquisition or language use, but also reflect on their perceived role in society, with certain languages becoming an asset or a disadvantage. In doing so, they 
make use of the prevailing linguistic hierarchy, where social positions are allocated to specific groups of speakers. Hence, they always position themselves in relation to others (P. Auer/ I. Dirim 2003, I. Oomen-Welke/ T. Pena Schumacher 2005). The focus of this study is to examine this positioning and the construction of particular roles for speakers of different languages in a society and the expression of language perception as negotiated on the linguistic market. Most interviews took place at home or in cafés and lasted from 45 to 120 minutes, allowing the participants to tell their story without being interrupted.

\section{(2) Participants}

The participants were recruited in rural and urban areas of Israel through social media and academic networks. The leading criterion was the profession of the participants: they all had to work as teachers in the Israeli education system. Purpose maximum variation sampling was employed during the participant recruitment process. The data corpus consisted of 18 Russian-Hebrew-English speakers who had all immigrated to Israel in the 1990s. External factors commonly experienced by these immigrants were the collapse of the Soviet Union and changes in the language education landscape in Israeli during this time period. At the time of immigration, the participants ages ranged from 2 and 41. Some of the immigrants had already been working in the educational system between 10 and 20 years.

\section{(3) Data Analysis}

The biographical interviews were transcribed and coded by three independent Russian and English speaking researchers using the annotation tool Eudico Linguistic Annotator (ELAN, H. Sloetjes/ P. Wittenburg 2008). As the actual language proficiency was not at the core of the study, the analysis focused on content (P. Mayring 2010) and reconstruction of arguments using the documentary interpretation method (A. Nohl 2010). The first step was the content analysis using deductive categorization. Based on P. Bourdieu's theory, language beliefs are expected to appear in topics such as language usefulness for life in general, for the school career and in the discussion of language legitimacy in interaction.

In the second step of the content analysis process, reconstructive methods of formulating and reflecting interpretation were applied. Following the transcription, a detailed formulating interpretation was prepared (R. Bohnsack 2014). Using reflecting interpretation, the interview text was analyzed in its form focusing not only on what is said, but on how it is said: How is a topic elaborated on, and in which framework of orientation is it dealt with? As biographical interviews are a social practice, they were analyzed not as factual experiences but as source of insight into the discursive construction of experience (G. Liebscher/ J. Dailey-O'Cain 2009). In order to uncover meanings in narrative data, particular attention was paid to the construction of arguments as in: „You shouldn't teach two languages at the same time. It hinders them [children], their mind, because you think differently in different languages."

After having coded all interviews, comparative analysis was applied in order to find patterns between the interviews (A. Nohl 2010). This step enabled the researcher 
to identify similarities and differences such as: "If a person came to this country, please speak the regional language [...]. I don't believe in cultural pluralism" as opposed to "I always compliment Circassians because they speak it and can write. I do it in front of the whole class." If the coding differed between the three researchers, the issue was resolved in a joint discussion.

\section{Findings}

The findings indicate significant deviations in immigrant teachers' language beliefs and reveal deep insights into their development over time. The research findings were coded into three different types of study participants: (3.1) Teachers who had immigrated to Israel at an adult age and were integrated in the school system, having experienced valorization of their linguistic expertise. These teachers perceive migrant-induced multilingualism as capital for themselves and for their students; (3.2) Teachers who had been socialized in the Israeli educational system as children and having experienced a monolingual setting at school, desired to assimilate into Israeli culture and as a result rejected the family language. In their teaching practice, these teachers consider languages other than Hebrew as hindering successful integration; (3.3) Teachers who had immigrated, similarly, at a young age, but have experienced positive reactions towards their multilingual skills at school or 'turning points' later in life. These teachers advocate for the use of different languages in everyday teaching practice and perceive multilingualism as capital for their students. These findings will be presented in the following sections, using prototypical examples from the data corpus.

\subsection{Professionally Integrated Adult Immigrant Teachers}

Teachers who had immigrated to Israel at an adult age with a teaching diploma and who were integrated in the school system (see "New immigrant teacher absorption" in section 2), have experienced valorization of their linguistic expertise.

\section{(1) Positioning on the Linguistic Market of School: Valorization}

Larissa (1991, 28 years old) In order to contextualize the examples, they start with the pseudonym of the person, the year of arrival and age at the point of arrival, followed by the translation in English by the author.: The school principal liked a lot that I know the system. By the time, I finished the teacher course and I had an idea of how languages are taught in the West.

Elana (1992, 41 years old): They [schools] were so interested, that today, at this college, they practically kiss the ground I walk on.

During the hiring process Elana and Larissa recall the great demand for multilingual teachers on behalf of their schools. Their pedagogical skills were accepted and cherished. In this description, the participants reveal how they perceived the process of integration: their pedagogical skills, combined with their multilingual skills, were considered an important asset. From a sociological and pedagogical perspective, their skills functioned as capital on the educational market of the host country and became 
a source of cherishment and valorization. However, they remember struggling with students' reaction to their accent in the beginning:

Larissa (1991, 28 years old): Children started to laugh. And the principal came to the class and said to them: "If you want to know mathematics, you will have mathematics taught by a Russian."

The interviewees remember being supported by the principal and laughed at by the students. But over the years they have experienced several situations of valorization from colleagues as well as the principal. Through this feedback they realize that being a speaker of an immigrant language does not contradict the fact of being an expert in their field. This positioning occurs not only in private situations but in front of Hebrew speaking students and colleagues. In Bourdieu's terms, migrant-induced multilingualism acquires legitimization on the linguistic market of school and can function as cultural capital.

(2) Biographical Turning Points

Reflecting about further changes in personal language use, the participants recall several turning points when being multilingual became a resource. Larissa remembers how she became aware of her linguistic self-confidence in a discussion with Hebrew speaking colleagues. A similar turning point was reconstructed in Elana's interview. Describing her work at a college, she mentions L. Vygotsky's work, Language and Thought", leaves the room where the interview takes place, and comes back with an edition in Hebrew, pointing to her name on the cover page:

Elana (1992, 41 years old): I was scientific leader of the project. The editor didn't speak Russian and only had the English version at hand. Once she calls me and asks: "Listen, I don't get a word, it is just not here" [...]. As I translated it from the Russian original I discovered how bad the English translation is.

Elana was asked for a scientific revision of the translation, because she is an expert in linguistics. She could read the original work in Russian, while the other experts used the translated version. In this feedback scenario, Elana experienced her combined expertise as unique capital and her work as a considerable contribution to the host society. The experienced valorization of their pedagogical skills and the acceptance of Russian language led the participants to develop a positive self-perception as migrant-induced multilinguals.

(3) Multilingualism as Everyday Practice at School

Over the years, the participants of this group have received positive feedback for their work and developed extreme pride of being both an expert in their field and the speaker of an immigrant language. The use of different languages in the school context is perceived as everyday practice. They even explain to the interviewer how important it is to be able to speak family languages for both students and teachers:

Larissa (1991, 28 years old): The Russian part speaks Russian among themselves, Hebrew part in Hebrew and everyone understands. You know, Russian language is for the most of us like slippers. I've lived here for 25 years, most of my life is in Hebrew, but it feels more 
comfortable, still, you know. When I am outside, during the recess, I don't want to wear high heels.

Elana (1992, 41 years old): I have two Russian-speaking colleagues at school, one in mathematics and one in biology, we speak Russian among ourselves [...], of course when others are not there, it is just not polite to speak a language others don't understand.

(4) Today's Language Beliefs

This experience with personal multilingualism as important for their professional integration finally results in a positive perception of multilingualism. Besides individual advantages for the students themselves, they consider multilingualism as socially important and stress it as a resource in today's life:

Irina (1991, 25 years old): I always promote languages, because I think that language is a resource. Every language. I always compliment Circassians because they speak it and can write, I do it in front of the whole class.

Elana (1992, 41 years old): Another language is a social mobility, it's social opportunities.

Professional integration and several turning points where the participants experienced a positioning as experts on the linguistic market of school allowed this group to develop a positive perception of migrant-induced multilingualism. This perception is reflected in their current belief in the legitimacy of languages other than the state language.

\subsection{Teachers Socialized in a Monolingual Setting as Children}

This extremely positive perception of multilingualism as capital differs substantially from the perception that was reconstructed in the next group. These teachers had immigrated to Israel as children and have experienced a monolingual setting at school. It is worth pointing out that this group immigrated at the same time as the first group (early 1990s). But these participants were children or young adults at the time of immigration.

(1) Negative Positioning as a Multilingual Speaker

In their biographies, they remember having received negative feedback on the Russian language:

Jana (1991, 13 years old): I understood quickly from a young age that there isn't anything great about Russian. And sometimes it's just better to keep quiet.

Moshe (1991, 6 years old): Russians were laughed at: "stinky Russian", they checked my sandwich! To see what we were eating, because Russians put pastrami in their sandwiches [...], they beat us [...] They laughed: „Russian”. When you say to a child, „you are Russian”, it sounds like a curse, ok? What a Russian you are! It's the same as if you say „Nigger.” Here and further, the quotes in italic were stated in English.

Being beaten, insulted or laughed at as reaction to the Russian language appears in several interviews. These incidents let Russian speakers realize that the language they used to speak is not accepted in the new environment and lets them develop a negative perception of migrant-induced multilingualism. Moshe, for example, narrates how 
much he does not identify himself with Russian culture and language. Even his Russian name sounds strange to him today, because he has been Moshe forever. But having pronounced this, he remembers that there was a time when he did use his Russian name:

Moshe (1991, 6 years old): It was in the first grade. I don't remember, how I presented myself before, but this I remember, my mom came and said „His name is Vyacheslav”. What a horrible name. I felt embarrassed [...]. I changed the name to Moshe.

(2) Language Rejection

A whole argumentation for identity reconstruction evolves as a consequence in these narrations, with Russian language as the leading criterion:

Moshe (1991, 6 years old): He is more Russian than me [...]. I build myself a level of Russianness, I searched parameters, how to behave. This was in many ways the mirror for me: If this is Russian [...], this is how I won't behave.

Nikita (1990, 10 years old): I didn't want to have any contact to Russians, but it somehow happened [...]. I didn't like it. I would have rather hung around with Israelis. Puberty, you know, we all make mistakes. They had a worse Hebrew than me, they had an accent.

Moshe (1991, 6 years old): I always said, when I grow up and have a girlfriend, I would never marry a Russian girl. And this is true, today, I am married to an Israeli.

Their choice of social environment became dependent on language, with Russian being a negative factor. The participants regret having had Russian-speaking contacts and feel the need to explain themselves, presenting these friendships as juvenile mistakes. In contrast, they share how much they appreciated Hebrew-speakers. This desire points out the perception of Hebrew as more prestigious. As a reaction to this feeling, the interviewees started to reposition themselves, eager to acquire the only legitimate capital - Hebrew:

Nikita (1990, 10 years old): In 9th grade I didn't have anything left from my accent except the $\mathrm{R}$ and I decided to remove it. I remember my feelings, how I forced myself to speak with a guttural R, I felt like a clown, like a total idiot [...]. Another incident that I remember then, and it was already on purpose: beginning from the 5th and 6th grade, I obsessively watched Israeli children's shows, which kids watched here when they were 5-6 years old. I understood that I was doing this so I could fill the void, to understand humor. Towards the end of 9th grade I was already speaking in Hebrew with no accent. I speak Hebrew on the highest level. Reading, writing, speaking. My Hebrew is better than in the majority of Hebrew-speakers.

Talia (1990, 14 years old): I don't have any big sentiments towards the Russian language. I didn't think that if the poem is not by Pushkin, it's not a real poem. That's why I think it was easier for me to learn Hebrew. Anyway, in a few months I was calmly speaking Hebrew. I entered Israeli society quickly.

This self-imposed ban, described as "obsessive", reveals the consciousness of the process of blending in. A process that required discipline and feeling like a clown was the price they had to pay in order to become part of the society. But the interviewees summarize that the price was worth it. As a criterion of blending in, the participants 
reveal that after a short period of time, no one could tell they were Russian. The pressure to adjust results in the pride of speaking the language better than native speakers. Having had a negative experience with migrant-induced multilingualism, and considering Hebrew to be the only legitimate language in their environment, they perceive integration as linguistic assimilation.

(3) Today's Language Beliefs

Speaking about today's language use at school, these participants underline the importance of the legitimate language and even point to the dangers of bilingual education:

Tova (1990, 13 years old): Language is the worldview, it affects a lot how children think. You shouldn't teach two languages at the same time. It hinders them, their mind, because you think differently in different languages. I want my children to think the way children think in Israel.

Nikita (1990, 10 years old): If a person came to this country, he has a choice; if he wants he can stay in his culture. This means that everyone will look at you sideways, this means that people won't understand you. If you want to enter and blend in, please speak the regional language, learn the local culture, watch local movies... I take this to be the duty of any immigrant. He has no right to cry if he is not given something. I don't believe in cultural pluralism.

In the linguistic market of school, the migrant-induced multilingualism does not constitute a capital or can even be the reason for bad positioning. Following this experience, the participants start to value the legitimate language which, by consequence, means to devalue other languages. It is seen as hindering in the process of integration into monolingual Israeli society. The developed language belief towards multilingualism in this setting is negative, which is finally reflected in the current pedagogical language belief of these immigrant teachers.

\subsection{Teachers Socialized in a Multilingual Educational Setting}

A different picture arises in teachers who similarly had immigrated at a young age, but have experienced a positive reaction towards migrant-induced multilingualism at school or "turning points" later in life.

\section{(1) Multilingualism as Capital in School Career}

Kostia (1991, 2 years old): We read Pushkin, I remember, we read poems and we learned them by heart. I liked it, I recited them at home in front of my parents. I like it, when the others see, how good I am at something „Look, I know Pushkin and poems and stuff”. I knew it all by heart.

In his last remark, the interviewee reveals his positive self-perception as a speaker of an immigrant language. He considers knowing Pushkin by heart as something he can be proud of. Other interviewees point to immigrant languages as capital in their school career: 
Jana (1991, 13 years old): I had Russian for final exam. We learned the language and the literature; it was very difficult, on the highest level. I liked it a lot. I had the highest mark in it, it was very important to me.

Looking back at their school days, the participants name Russian alongside French, Arabic or Spanish as important languages:

Olga (1991, 11 years old): In Israel, popular languages are Arabic, French and Russian.

Julia (1990, 1 year old): English and Russian. I know languages well, I know Spanish too, I understand quickly.

These interviewees have apparently not experienced a negative reaction to migrantinduced multilingualism. In contrast to the previous group, which is extremely proud of having learned Hebrew very fast and emphasizes that they never felt Russian, these interviewees are proud of the skills they have: being multilingual in Russian, Hebrew and other socially accepted and prestigious languages. Compared to the first group of participants, in these statements there is no decision-making or rejection of Russian. The idea of constructing a new identity through a name change or choice of friends is not mentioned. Questions concerning language norms at school seem strange:

Kostia (1991, 2 years old): Whatever they spoke, I answered, sometime like this sometime like that. The way one of us started, the other would just pick up.

They do not understand the question or do not remember, which suggests that during their socialization the topic of language selection was not a concern at school. When answering the question on how peers and teachers reacted to languages other than the state language, they say:

Julia (1990, 1 year old): I don't remember, it was ok.

Kostia (1991, 2 years old): Not that... nothing special. It was the same like it was in Hebrew, if you are chatting, in Hebrew, in English or in Russian, the teacher doesn't like it.

Even when the question is repeated on several occasions, e.g. what languages where spoken during recess, the same pattern appears. The interviewees do not understand why the question is asked and state what they perceived as normal - that there was no rule for what students are supposed or not supposed to speak.

\section{(2) Today's Language Belief: Multilingualism as Capital}

For this last group of study participants, their experience with language use was different and therefore impacted the developed belief about multilingualism:

Natalia (1990, 2 years old): You need to know this and this, you need to have that and that.

Kostia (1991, 2 years old): I pick the best from there and from here. We became so successful because we grew up with all this. I don't regret to have grown up speaking Russian.

This development of the positive self-perception as belonging to different languages can be reconstructed through the interviewees' line of argumentation. The way they 
stated their idea of belonging reflects their perception of what S. Hall (1990) calls "hybrid identity" as an everyday matter. They not only feel that they can speak languages other than Hebrew and be Israeli at the same time, but the idea of a hybrid identity is seen as the only right way to exist and considered the foundation of their "successful" development. This positive experience finally leads to a positive perception of multilingualism for themselves and for society in general:

Julia (1991, 1 year old): It is always a plus, there are many Russians in Israel, and it is good for the brain, to know two languages.

Natalia (1990, 1 year old): Russian language helps me a lot at work. It is always a help. I feel that I can help the others more easily. I think the more languages you know, the better.

Kostia (1991, 2 years old): [Speaking of a particular classmate] She speaks Russian so well. Better than I do. It is so beautiful. I think, every other language is good. [Speaking of different classmate] She is clever, but she doesn't speak Russian.

This last statement reveals the prevailing language belief in these immigrant teachers. They perceive migrant-induced multilingualism as capital for children and for the society in general. This perception reflects the participants' own school biography. Having experienced use of migrant languages as everyday praxis, they reproduce this belief in their current professional situation. However, this reconstructed perception is not a fixed concept, but rather subject to change. Participants who have experienced a monolingual setting at school, but a valorization of migrant-induced multilingualism later in life, reveal a change in language beliefs:

Olga (1991, 11 years old): I got used to always feeling slightly second-rate. This is normal. You understand that you are less rich, that you are not so smart, that you have less opportunities. And you submit to this, because that's life. But here you start to get a feeling, you see, that you are regarded with respect. And they say, listen Chekhov wrote in Russian, and you can read it. And all of a sudden you understand that someone is jealous of YOU, and your whole worldview changes.

Jana (1991, 13 years old): I spent so many years trying to write and learn Hebrew [...]. And I began to appreciate some things differently for myself. What was I supposed to? What was it all for? Was it necessary and was it right? I need to find some kind of middle, to remain Russian, to speak Russian, this doesn't make me less of an Israeli.

These participants experienced the monolingual context in their own school setting. After having gotten used to feeling inferior and having to decide between languages, at a certain point they experienced a valorization of what they learned to initially hide. They realized over time that migrant-induced multilingualism does not need to be a hindrance, but can be a source of respect. The valorization appears in front of nonmigrant-speaking students and makes them "be jealous of you". This shift in perception led them to question the pre-existing language beliefs and develop a new perception of multilingualism as a capital.

\subsection{Limitations: Stated Teaching Practice}

As presented in the previous section, language beliefs are subject to transformation. While many immigrant teachers reproduce the experienced monolingual approach, 
which sets limitations to their function as change agents for the multilingual perspective, this perception is not fixed and stable. It can develop into a perception of migrant-induced multilingualism as a capital. This change, however, requires a change in societal feedback, as was reconstructed in language-biographical turning points in which the interviewees experienced positive changes in societal attitudes towards migrant-induced multilingualism.

However, this perception is not reflected in their everyday teaching practice - in the strategies of action. Asked about the use of languages in everyday school life, immigrant teachers reveal a monolingual approach in class, including separate use of two languages:

Elana (1992, 41 years old): I teach literature in Hebrew. In Russian we speak Russian, but otherwise, of course, in Hebrew., No language develops well, whether Russian nor nothing if you mix them all the time. It is called semi-lingualism and this is dangerous.

Shaul (2000, 21 years old): I should, I am convinced that I should do it in Hebrew. It will be hard for them to learn Hebrew because of softies like me.

Shaul admits to switching to languages other than Hebrew when explaining new material. But at the same time, he doubts the legitimacy and the effectiveness of this teaching practice. Also other teachers who show valorization of multilingualism on the individual and societal level reveal insecurity when speaking about actual language use in everyday teaching. These findings suggest that additional research and discussion is necessary on the need for the inclusion of multilingual practices in professional teacher training.

\section{Conclusion}

While this study relates to a specific historical and national context, the findings are yet crucial in the light of current migration patterns and contribute to a reflected understanding of linguistic diversity management which supports a paradigm shift in the educational approach towards multilingualism. Immigrant teachers can constitute a considerable resource in this transformation process, giving an example of and advocating for multilingualism. However, the perception of language as capital strongly depends on their own experience with migrant-induced multilingualism. The immigrant background does not per se result in multilingual competences and existing multilingual competences do not automatically lead to a perception of multilingualism as an asset. As reconstructed in immigrant teachers' biographies, this development is subject to socio-political contexts and the prevailing language ideology in society as it is reflected on the linguistic market of school. When multilingualism is included as an asset for learning processes and an academic career, teachers reproduce this belief in their daily professional practice. For teachers who had immigrated as adults, the development of language beliefs strongly depends on how immigrant languages are assigned in the labor and education market. Opportunity for professional integration, based on acceptance of pedagogical and linguistic skills, allows for an emergence of perception of multilingualism as capital. Similarly, in teachers who have been socialized in the school system as children and in their youth, the societal management 
of multilingualism also shapes their current language beliefs. Teachers who have experienced multilingualism as legitimate in everyday interaction and as actual capital for the academic or professional career, consider migrant-induced multilingualism a significant asset for their students and for society as a whole. In a setting where only the state language is accepted, participants develop language beliefs that reproduce multilingualism as a deviation from the norm and consider languages other than Hebrew irrelevant or even hindering.

These beliefs, however, are not stable and fixed concepts but rather fluent and open to transformation, as findings on biographical turning points illustrate. These findings open a further question for pedagogical research and teacher education training: How can these turning points, which offer a rich array of reflexive moments, be examined and made relevant for all participants in teacher training programs? Finally, the study results underline the importance of professional training and valorization of immigrant teachers to open a further question on the importance of methodological professionalization in multilingual teaching practices.

\section{References}

Ağırdağ, O./ K. Jordan's/ M. van Houtte (2014), Speaking Turkish in Belgian Primary Schools: Teacher Beliefs versus Effective Consequences. In: Journal of Social Sciences of the Turkish World 70, 7-28.

Auer, P./ İ. Dirim (2003), Socio-cultural orientation, urban youth styles and the spontaneous acquisition of Turkish by non-Turkish adolescents in Germany. Constructions of Youth Identities. In: K.K. Androutsopoulos/ A. Georgakopoulou (eds.), Discourse Constructions of Youth Identities. Amsterdam, 223-246.

Baker, C. (2011), Foundations of bilingual education and bilingualism. Clevedon.

Baumert, J./ M. Kunter. (2006), Stichwort: Professionelle Kompetenz von Lehrkräften. In: Zeitschrift für Erziehungswissenschaft 9 (4), 469-520.

Berger, E. (2001), Absorption problems in a multicultural society: selected issues of professional integration of immigrant teachers from the former Soviet Union into the education system in northern Israel. Unpublished Doctoral Thesis. Anglia Polytechnic University, UK. Date of access: 20.09. 2016. http://library.macam.ac.il/study/pdf_files/d9137.pdf

Blommaert, J. (1999), Language Ideological Debates (Language, Power and Social Process). Berlin/ Boston.

Blommaert, J. (2010), The Sociolinguistics of Globalization. Cambridge

Bohnsack, R. (2014), Rekonstruktive Sozialforschung: Einführung in qualitative Methoden. Opladen/ Toronto.

Bourdieu, P./ J.-C. Passeron (1998), Die Illusion der Chancengleichheit. Stuttgart.

Bourdieu, P. (1990), Was heißt sprechen? Die Ökonomie des sprachlichen Tausches. Wien.

Bräu, K./ V.B. Georgi/ Y. Karakaşoğlu-Aydın/ C. Rotter (2013), Lehrerinnen und Lehrer mit Migrationshintergrund: Zur Relevanz eines Merkmals in Theorie, Empirie und Praxis. Münster/ New York/ München/ Berlin. 
BReg. (2015), Rede von Bundeskanzlerin Angela Merkel beim Deutschen Fürsorgetag am 17. Juni 2015. Date of access: 04.04. 2017. http:/www.bundesregierung. de/Content/DE/Rede/2015/06/2015-06-18-merkelfuersorgetag.html.

Burteisen, J. (2003), Zur sprachlichen Integration von Immigranten aus der ehemaligen Sowjetunion in Israel. In: U. Reitemeier (ed.), Sprachliche Integration von Aussiedlern im internationalen Vergleich. Mannheim, 221-245.

CNN Wire Staff (2010), Education secretary says U.S. needs more minority teachers. $\begin{array}{llll}\text { Date of } & 04.04 . & \end{array}$ http://edition.cnn.com/2010/POLITICS/08/28/duncan.minority.teachers/

Creese, A./ A. Blackledge (2010), Translanguaging in the Bilingual Classroom: A Pedagogy for Learning and Teaching? In: The Modern Language Journal 94 (1), $103-115$.

Cummins, J. (2010), Language, power, and pedagogy: Bilingual children in the crossfire (Bilingual education and bilingualism). Clevedon/ Buffalo.

Franceschini, R. (2002), Sprachbiographien: Erzählungen über Mehrsprachigkeit und deren Erkenntnisinteresse für die Spracherwerbsforschung und die Neurobiologie der Mehrsprachigkeit: In K. Adamzik/ E. Roos (eds.), Biografie linguistiche, Bulletin VALS-ASLA 76, 19-33.

Freeman, D. (2001), Teacher learning and student learning in TESOL. In: TESOL Quarterly 35 (4), 608-609.

Fürstenau, S. (2016), Multilingualism and School Development in Transnational Educational Spaces. Insights from an Intervention Study at German Elementary Schools. In: A. Küppers/ B. Pusch/ P. Uyan-Semerci (eds.), Bildung in transnationalen Räumen: Education in transnational spaces. Wiesbaden, 71-90.

Gal, S. (2006), Migration, Minorities and Multilingualism: Language Ideologies in Europe. In: C. Mar-Molinero/ P. Stevenson (eds.), Language Ideologies, Policies and Practices. Language and the Future of Europe. Houndsmill, 13-27.

García, O. (2013), Theorizing and enacting translanguaging for social justice. In: A. Blackledge/ A. Creese (eds.), Heteroglossia as practice and pedagogy. New York, 192-216.

García, O./ W. Li (2014), Translanguaging: Language, bilingualism and education. Basingstoke/ Hampshire/ New York.

Garrett, P. (2010), Attitudes to language. Cambridge.

Gkaintartzi, A./ A. Kiliari/ R. Tsokalidou (2013), 'Invisible’ bilingualism - 'invisible' language ideologies: Greek teachers' attitudes towards immigrant pupils' heritage languages. In: International Journal of Bilingual Education and Bilingualism 18 (1), 60-72.

Grosjean, F. (2010), Bilingual: Life and reality. Cambridge, Mass.

Hall, L. (2005), Teachers and Content Area Reading: Attitudes, Beliefs and Change. In: Teaching and teacher Education 21, 403-414.

Hall, S. (1990), Cultural Identity and Diaspora. In: P Williams/ L. Chrisman (eds.), Colonial Discourse and Post-Colonial Theory. A Reader, 392-403. New York.

Hélot, C./ A. Young (2006), Imagining Multilingual Education in France: A language 
and cultural awareness project at primary level. In: O. García/ T. SkutnabbKangas/ M.E. Torres-Guzmán (eds.), Imagining multilingual schools: Languages in education and globalization. Clevedon, 69-90.

Ingersoll, R./ H. May (2016), Minority Teacher Recruitment, Employment and Retention: 1987 to 2013. Stanford.

Irvine, J.T./ S. Gal (2000), Language ideology and linguistic differentiation. In: P. V. Kroskrity (ed.), Regimes of language: Ideologies, polities, and identities. Santa Fe, 35-84.

Krüger-Potratz, M. (2009), Migration als Herausforderung für Bildungspolitik. In: R. Leiprecht (ed.), Schule in der Einwanderungsgesellschaft: Ein Handbuch. Schwalbach, 56-82.

Lengyel, D./ L. Rosen. (2015), Minority teachers in different educational contexts.: Introduction. In: Tertium Comparationis. Journal für International und Interkulturell Vergleichende Erziehungswissenschaft 21 (2), 153-160.

Leutwyler, B./ C. Mantel/ D.S. Petrović/ B. Dimitrijević/ B. Zlatkovic (2014), Teachers Beliefs about Intercultural Education: Different Levels of Intercultural Sensitivity in Schooling and Teaching. In: Educational Research 5 (8), 280-289.

Liebscher, G./ J. Dailey-O'Cain (2009), Language attitudes in interaction. In: Journal of Sociolinguistics 13 (2), 195-222.

Mayring, P. (2010), Qualitative Inhaltsanalyse. In: G. Mey/ K. Mruck (eds.), Handbuch Qualitative Forschung in der Psychologie. Wiesbaden, 601-613.

Nohl, A. (2010), Narrative Interview and Documentary Interpretation. In: R. Bohnsack/ N. Pfaff/ W. Weller (eds.), Qualitative analysis and documentary method in international educational research. Opladen, 195-217.

Oomen-Welke, I./ T. Pena Schumacher (2005), Sprachenlernen - Biographische Rekonstruktionen zweisprachiger Schulkinder. In: V. Hinnenkam/ K. Meng (eds.), Sprachgrenzen überspringen. Sprachliche Hybridität und polykulturelles Selbstverständnis, 289-323. Tübingen.

Oomen-Welke, I. (2013), Mehrsprachigkeit in der Klasse wahrnehmen, aufgreifen, fördern. Stuttgart.

Pajares, M.F. (1992), Teachers' Beliefs and Educational Research: Cleaning Up a Messy Construct. In: Review of Educational Research 62 (3), 307-332.

Pavlenko, A./ A. Blackledge (2004), New theoretical approaches to the study of negotiation of identity in multilingual contexts. In: A. Pavlenko/ A. Blackledge (eds.), Negotiation of identities in multilingual contexts. Clevedon, 1-33.

Poarch, G./ E. Bialystok (2017), Assessing the implications of migrant multilingualism for language education. In: Zeitschrift für Erziehungswissenschaft 20 (2), 175-191.

Pulinx, R./ V. van Avermaet (2015), Integration in Flanders (Belgium) - Citizenship as achievement: How intertwined are 'citizenship' and 'integration' in Flemish language policies? In: Journal of Language and Politics 14 (3), 335-358.

Putjata, G. (in press a) Multilingualism for Life - Transforming Language beliefs in education professionals: Insights from an intervention study in Germany. In: Language Awareness, forthcoming. 
Putjata, G (in press b) Immigrant teachers' integration and transformation of the linguistic market. In: Language and Education, forthcoming.

Putjata, G./ H. Olfert/ S. Romano (2016), Mehrsprachigkeit als Kapital Möglichkeiten und Grenzen des Moduls 'Deutsch für Schülerinnen und Schüler mit Zuwanderungsgeschichte' in Nordrhein-Westfalen. In: ÖDaF - Mitteilungen 32 (1), 34-44.

Reusser, K./ C. Pauli/ A. Elmer (2011), Berufsbezogene Überzeugungen von Lehrerinnen und Lehrern. In: E. Terhart (ed.), Handbuch der Forschung zum Lehrerberuf. Münster, 478-496.

Schalley, A./ S. Eisenchlas/ D. Guillemin (2015), Multilingualism and literacy: attitudes and policies. In: International Journal of Multilingualism 12 (2), 151161.

Schmid, M. (2010), New perspectives on L1 attrition. In: Bilingualism: Language and Cognition 13 (1), 1-83.

Shohamy, E. (2006), Imagined multilingual schools: How come we don't deliver. In: O. García/ T. Skutnabb-Kangas/ M.E. Torres-Guzmán (eds.), Imagining multilingual schools: Languages in education and glocalization. Clevedon, 171183

Sloetjes, H./ P. Wittenburg (2008), Annotation by category - ELAN and ISO DCR. In: Proceedings of the 6th International Conference on Language Resources and Evaluation.

Spolsky, B./ E. Shohamy (1999), The languages of Israel: Policy, ideology and practice. Clevedon.

Staub, F.C./ E. Stern (2002), The nature of teachers' pedagogical content beliefs matters for students' achievement gains: Quasi-experimental evidence from elementary mathematics. In: The Journal of Educational Psychology 94 (2), 344355.

Stevenson, P. (2011), Migration und Mehrsprachigkeit in Europa. Diskurse über Sprache und Integration. In: L. Eichinger/ A. Plewnia, M. Steinle (eds.), Sprache und Integration. Tübingen, 13-27.

Tracy, R. (2008), Wie Kinder Sprachen lernen: Und wie wir sie dabei unterstützen können. Tübingen.

Woods, D. (1996), Teacher Cognition in Language Teaching. Cambridge.

Young, A. S. (2014), Looking through the language lens: Monolingual taint or plurilingual tint? In: J. Conteh/ G. Meier (eds.), The Multilingual Turn in Languages Education: Opportunities and Challenges. Bristol, 89-109. 